\title{
Genetic Relationship between Tongka Langit Bananas (Musa troglodytarum L.) from Galunggung and Maluku, Indonesia, Based on ITS2
}

\author{
Fenny Martha Dwivany ${ }^{1,2,3^{*}}$, Giasintha Stefani' ${ }^{1}$ Agus Sutanto ${ }^{5}$, Husna Nugrahapraja ${ }^{1,2}$, Ketut Wikantika ${ }^{3,4}$, Adriana \\ Hiariej ${ }^{6}$, Topik Hidayat ${ }^{7}$, I. Nyoman Rai ${ }^{3,8}$, Nisrina Sukriandi ${ }^{1}$
}

${ }^{1}$ School of Life Sciences and Technology, Institut Teknologi Bandung, Bandung, Indonesia,

${ }^{2}$ Bioscience and Biotechnology Research Center, Institut Teknologi Bandung, Bandung, Indonesia,

${ }^{3}$ Bali International Research Center for Banana, Udayana University, Bali, Indonesia

${ }^{4}$ Center of Remote sensing, Institut Teknologi Bandung, Bandung, Indonesia,

${ }^{5}$ Indonesian Tropical Fruit Research Institute, Indonesian Ministry of Agriculture, Solok, Indonesia

${ }^{6}$ Universitas Pattimura, Ambon, Indonesia

'Universitas Pendidikan Indonesia, Bandung, Indonesia

${ }^{8}$ Udayana University, Bali, Indonesia

\section{ARTICLE INFO}

Article history:

Received October 15, 2019

Received in revised form June 7, 2020

Accepted June 30, 2020

KEYWORDS:

Musa troglodytarum L.,

Tongka Langit banana,

ITS2,

Galunggung,

Maluku

\begin{abstract}
Tongka Langit or Fe'i banana (Musa troglodytarum L.) has the T genome and a very high content of beta-carotene. It only grew and spread around the regions of Maluku islands and Papua. However, recently our team found this banana on the foot of mount Galunggung, West Java, so this raised the question about its origin. The objective of this study was to understand the genetic relationship between Tongka Langit from Galunggung and Maluku islands and compared it with other bananas with different genomes. Genetic diversity analysis was done using ITS2 DNA marker and dendrogram analysis showed three groups. From the comparison of the ITS2 sequences, there were no difference (100\% identity) between the ITS2 sequence of Tongka Langit originating from Galunggung and Maluku. In conclusion, based on the ITS2 marker, the Tongka Langit were more distantly related to cultivars with $A$ and $B$ genomes, and there was no difference in the ITS2 sequence of Tongka Langit originating from Galunggung and Maluku. To the best of our knowledge, there is no previous report of genetic relationship between Tongka Langit from Galunggung and other regions.
\end{abstract}

\section{Introduction}

Tongka Langit banana (Musa troglodytarum L.) is a cultivar with unique characteristics such as upright fruit bunches (Hiariej and Karuwal 2015), magenta colored resin, large fruits and reddish orange pulp (rich in $\beta$-carotene) that gives it the potential to be developed into an alternative staple food. The history of the breeding of Tongka Langit banana is unknown, but it is suspected to originate from Musa lododensis (based on its DNA), Musa maclayi (based on morphology), and Musa peekelii (Ploetz et al. 2007).

Initially Tongka Langit banana was thought to come from French Polynesia which was then brought

\footnotetext{
* Corresponding Author

E-mail Address: fenny@sith.itb.ac.id
}

westward reaching Melanesia (Maluku islands, Papua, West Pacific). In Indonesia, Tongka Langit banana was known only to spread to Maluku and Papua (Lim 2012). However, a banana plant called Ranggap from Galunggung, West Java, was recently noticed to have similar characteristics as Tongka Langit banana, which gave rise to questions about the origin of the Ranggap banana plant. According to the people in Galunggung, Ranggap banana was already present before the eruption of Mount Galunggung in 1982. We sent an expedition to Galunggung at the end of 2017 and confirmed that Ranggap banana had the same morphological characteristics as Tongka Langit banana from Maluku, therefore we considered them to be the same species.

The aim of this research was to determine the phylogenetic relationship between the banana from 
Galunggung and the one from Maluku. Phylogenetic analysis was performed using the ITS2 molecular marker to study the diversity of banana species. ITS 2 could be used as a molecular marker because it has sufficient variability to be able to differentiate between banana cultivars, it has a high copy number and it is short, thereby making it easier for DNA isolation, amplification, and analysis.

\section{Materials and Methods}

\subsection{Materials}

In this research several cultivars with different genomes, which came from various regions of Indonesia, were used and list of the cultivars can be seen in Table 1. Sample collection in Galunggung was performed in September 16, 2017. Other banana samples are shown in Figure 1 were obtained from Bali, East Java, Maluku, and Papua.

\subsection{Methods}

\subsubsection{Measurement of the Physical Factors of} the Growth Environment of the Galunggung Tongka Langit Banana

Soil temperature was measured using a Weksler thermometer. The thermometer was inserted into the ground until the metal part was buried. After three minutes, the temperature could be read on the scale (Globe 2014). Soil temperature was measured three times to get the average temperature. Air temperature and relative humidity was measured with a sling psychrometer. The instrument was swirled for three minutes, after which the temperatures on the two thermometers were recorded and lined up on the scale to read the \% relative humidity (Thomson 1986). The measurements were performed with three repetitions.

Light intensity was measured with a Lux meter. The light sensor of the equipment was covered and the zero knob was pressed, the cover was removed and the proper range of measurement was selected

Table 1. List of banana accessions sampled and their genomes

\begin{tabular}{lll}
\hline Sample no. & Banana cultivars & Genome \\
\hline 1 & Mas Bali & AA \\
2 & Tulang/Ambon Hijau & AAA \\
3 & Seribu & AAB \\
4 & Kepok Tanjung & ABB \\
5 & Rojo Molo & AAA \\
6 & Tembaga & AAA \\
7 & Klopok/Sobo & ABB \\
8 & Lumut & AAA \\
9 & Mas Marlin & AA \\
10 & Klutuk & BB \\
11 & Klutuk Wulung & BB \\
12 & Mas & AA \\
13 & Bile & AB \\
14 & Ambon Hijau Kerdil & AAA \\
15 & Cavendish Sunpride & AAA \\
16 & Tongka Langit Galunggung & TT \\
17 & Tongka Langit Maluku & TT \\
18 & Kepok Jawa & ABB \\
\hline
\end{tabular}

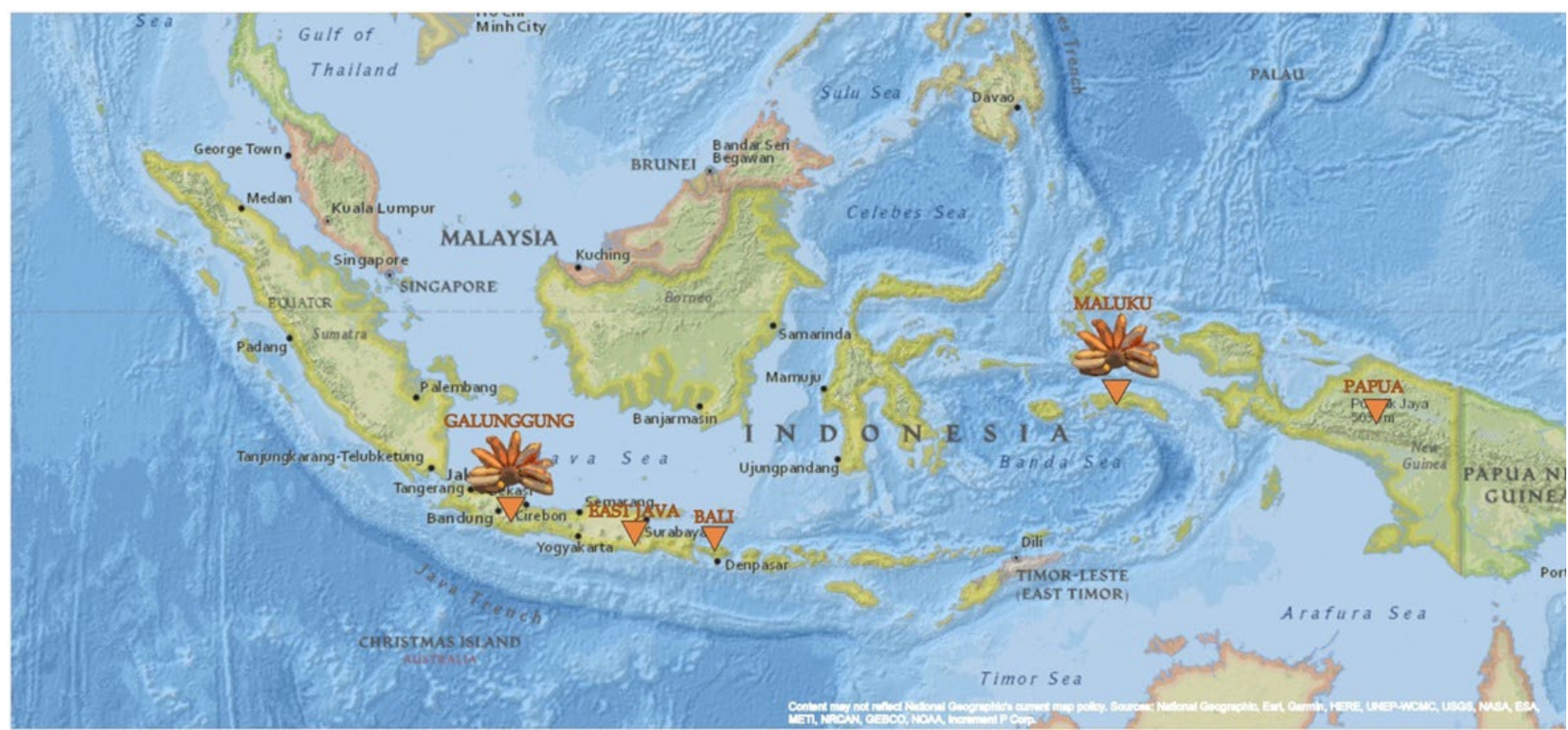

Figure 1. Tongka Langit and other bananas sampling locations in Galunggung, Maluku, East Java, and Bali 
until a number appeared on the screen (STEP Systems $\mathrm{GmbH}$ 2005). The sensor was placed above the head in a horizontal position facing above for three minutes. The average measurement knob was pressed to obtain the average light intensity, then the sensor was covered again. The measurement was performed with three repetitions.

Sampling of the soil was performed to get the soil profile using an Auger. The ground was drilled with the Auger $30 \mathrm{~cm}$ deep, the Auger was tilted and pulled out slowly so that the horizontal position of the soil remained constant (Wonkee Donkee Tools 2018).

\subsubsection{Banana Sampling}

Sampling of the 18 banana cultivars was performed by cutting part of the leaves that were still rolled up using a cutter that had been sterilized with $70 \%$ ethanol. The banana leaves were placed in a $50 \mathrm{ml}$ Falcon tube containing two grams of silica gel. The Galunggung Tongka Langit banana sampel was obtained from an expedition to Padakembang village, Tasikmalaya district, West Java and the Maluku Tongka Langit sample was obtained from Maluku. The other samples were obtained from various regions in Bali and Java.

\subsubsection{DNA Isolation and Analysis}

DNA isolation of the banana samples were performed using the CTAB protocol (Doyle 1990). PCR was performed using ITS2 primers as molecular markers where $5 \mu \mathrm{l}$ samples were mixed with $45 \mu \mathrm{l}$ PCR MasterMix (GoTaq ${ }^{\circledR}$ Green Master Mix [Promega Co. USA], Nuclease-free water, ITS2 primers) in a PCR tube. The tubes were placed in the PCR machine and PCR was performed at temperatures $94^{\circ} \mathrm{C}$ for denaturation, $55^{\circ} \mathrm{C}$ for annealing and $72^{\circ} \mathrm{C}$ for elongation. The sequence of the ITS2 primers is shown in Table 2.

Amplicon (35 $\mu \mathrm{l})$ from each sample was purified and sent to Macrogen Korea for DNA sequencing. The sequencing data were analyzed with Codon Code

Table 2. ITS2 primers sequences used for PCR (Gu et al. 2013)

\begin{tabular}{lll}
\hline $\begin{array}{l}\text { Primer } \\
\text { name }\end{array}$ & \multicolumn{1}{c}{$\begin{array}{c}\text { Sequence } \\
\left(5^{\prime} \rightarrow 3^{\prime}\right)\end{array}$} & $\begin{array}{l}\text { Amplicon } \\
\text { size }(\mathrm{bp})\end{array}$ \\
\hline ITS2-S2F & ATGCGATACTTGGTGTGAAT & 205-227 \\
\hline ITS2-S3R & GACGCTTCTCCAGACTACAAT & \\
\hline
\end{tabular}

Aligner software to form contigs. The ITS2 contigs were then annotated and their secondary structures were analyzed with ITS2 Ribosomal RNA Database software. The annotated sequences were analyzed using BLASTn (Nucleotide Basic Local Alignment Search Tool) program (Altschul et al. 1997), multiple sequence alignment was performed using ClustalW (Thompson et al. 1994), and a maximum-likelihood dendrogram was constructed using MEGA6 (Tamura et al. 2013). ITS2 Database (http://its2.bioapps. biozentrum.uni-wuerzburg.de/) with e-value cut off less than $1 \mathrm{e}-16$ and model with highest transfer helices was selected to predict the ITS2 secondary structure. ITS2 motif prediction was also done using ITS2 Database, with e-value less than 0.01 and using Viridiplantae model (Keller et al. 2009; Koetschan et al. 2010). WebLogo 3 (http://weblogo.threeplusone. $\mathrm{com} /$ ) (Crooks et al. 2004) was used to illustrate consensus representation of ITS2 nucleotide multiple sequence alignment and each logo consensus for each motif was juxtaposed to its position in the ITS2 secondary structure.

\section{Results}

In this study, we compared Tongka Langit banana from Galunggung and from Maluku. Figure 2 shows the leaves of Tongka Langit banana from Galunggung were dark green, shiny and had no wax. Compared to Tongka Langit banana from Maluku, there were no differences in morphology between these two bananas. Physical environment growth conditions

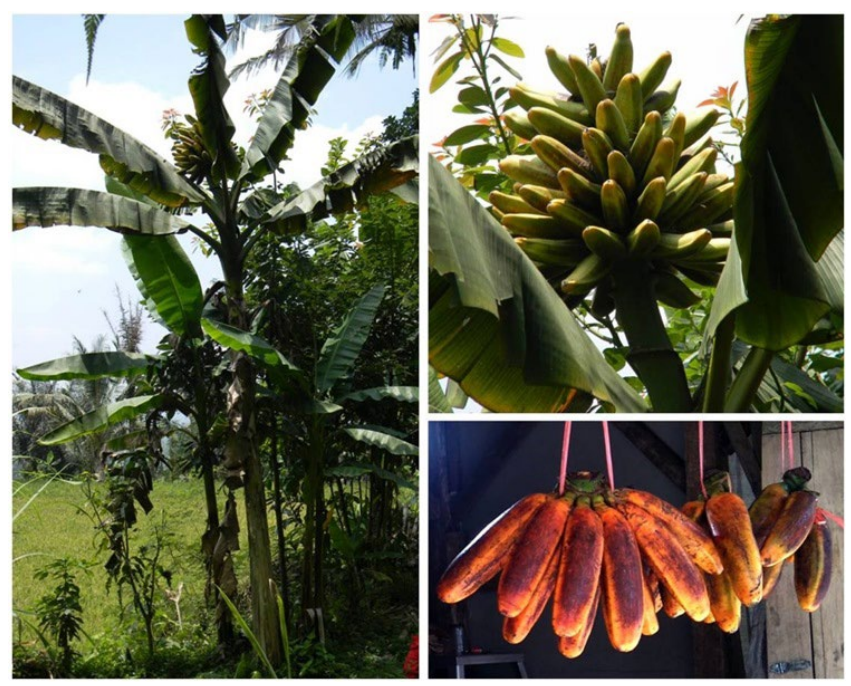

Figure 2. Tongka Langit banana 
between Tongka Langit banana in Galunggung and Maluku can be seen in Table 3. The Galunggung Tongka Langit banana could grow at $27.7^{\circ} \mathrm{C}$ average air temperature, $25 \%$ average humidity, $30.8^{\circ} \mathrm{C}$ average soil temperature, high light intensity and sandy soil texture. On the other hand, air temperature in Maluku varied from 13 up to $32^{\circ} \mathrm{C}$. Such was also the case for the relative humidity where Tongka Langit banana grew. The Galunggung area had 25\% relative humidity, while the relative humidity of the areas in Maluku where the Tongka Langit banana grew varied from less than $10 \%$ up to $30 \%$. Based on observation, the soil texture where the Galunggung Tongka Langit banana grew was sandy, which was the same soil texture as in Wakal, Passo and Saparua Islands where the Maluku Tongkat Langit banana grew.

The molecular markers used in this research were ITS2 primers. Electrophoresis of the ITS2 amplicons in Figure 3 showed that all 18 samples could be amplified and the size was less than $500 \mathrm{bp}$.

Based on Figure 4 and 5, the alignment and secondary structure comparison of the ITS2 sequences of Tongka Langit bananas from Galunggung and Maluku showed no differences in the nucleotide sequence (100\% identity). Figure 6 shows multiple alignment of ITS2 sequences of Tongka Langit and other banana cultivars from other genomes. The alignment showed several differences that were located at nucleotide sequence number 3, 20, 22, $25-44,93,99,120,160,181$, and 187 , which is shown by colored letters and a red colored box. Tongka Langit banana had the shortest ITS2 sequence, 208 bp long, compared to other banana cultivars with different genomes, which ranged from 218 to $220 \mathrm{bp}$. The secondary analysis showed that ITS2 secondary structure of Tongka Langit banana is consisted of four helices.

Dendrogram based on ITS2 marker is shown in Figure 7. The dendogram shows three groups. Group 1 consisted of cultivars with $A A$ and AAA genomes. Group 2 consisted of cultivars with $B B, A B B, A A B$,

Table 3. Physical environment growth conditions of Tongka Langit banana in Galunggung and Maluku

\begin{tabular}{lll}
\hline Parameter & $\begin{array}{l}\text { Galunggung Tongka } \\
\text { Langit }\end{array}$ & $\begin{array}{l}\text { Maluku } \\
\text { Tongka Langit }\end{array}$ \\
\hline Air temperature & $27.7^{\circ} \mathrm{C}$ & $13-32^{\circ} \mathrm{C}$ \\
Relative humidity & $25 \%$ & $10-30 \%$ \\
Light intensity & High & High \\
Soil texture & Sandy & $\begin{array}{c}\text { Sandy, sandy } \\
\text { silt loam, } \\
\end{array}$ \\
& & silty loam \\
\hline
\end{tabular}

and $\mathrm{AB}$ genomes. Group 3 which consisted of Tongka Langit from Galunggung and Maluku with TT genomes, was distantly related to other cultivars with different genomes.

\section{Discussion}

Tongka Langit banana from Galunggung had several unique characteristics such as upright fruit bunches and magenta to purple colored resin, maroon red colored peel when ripe. Tongka Langit banana from Maluku also had upright fruit bunches, purple colored resin and large fruits, yellowish orange to maroon red colored peel with the same leaf characteristics as the Galunggung Tongka Langit banana.

When comparing with the physical environment where the Maluku Tongka Langit bananas grew (Hiariej and Karuwal 2015), the physical conditions of both areas were not exceptionally different. There were variations in the physical environment growth conditions of Tongka Langit banana in Maluku, and also the case for the relative humidity where Tongka Langit banana grew. Therefore, it could be concluded that Tongka Langit banana could grow in a quite wide range of physical environmental conditions.

ITS2 primers designed by Gu et al. (2013) were chosen to see the genetic variations between Tongka Langit cultivars and cultivars with other genomes. ITS2 primers were universal primers that could amplify ITS2 region because ITS2 is a molecular marker that was often used in plants because it had high variations to be able to differentiate the various banana cultivars. In addition, in previous study our group has also used the ITS2 primers to study various banana cultivars from Bali and other regions in Indonesia (Meitha et al. 2020; Dwivany et al. 2020). According to the literature, the size of ITS2 of bananas ranged from 205 to $227 \mathrm{bp}$, however, the results here were longer. This was because the ITS2 amplicon also contained part of 5.8S and $26 \mathrm{~S}$ genes. The ITS2 primers contained sequences from the $5.8 \mathrm{~S}$ and 265 genes to ensure that the primers still could anneal when mutations were present in the ITS2 sequence (Yao et al. 2010).

ITS2 secondary structure of Tongka Langit banana is consisted of four helices. These helices, namely helix I to IV, is proved to be highly conserved in Eukaryotes (Schultz et al. 2005). Helix III is the longest among all helices and is unique for containing a UGGU 


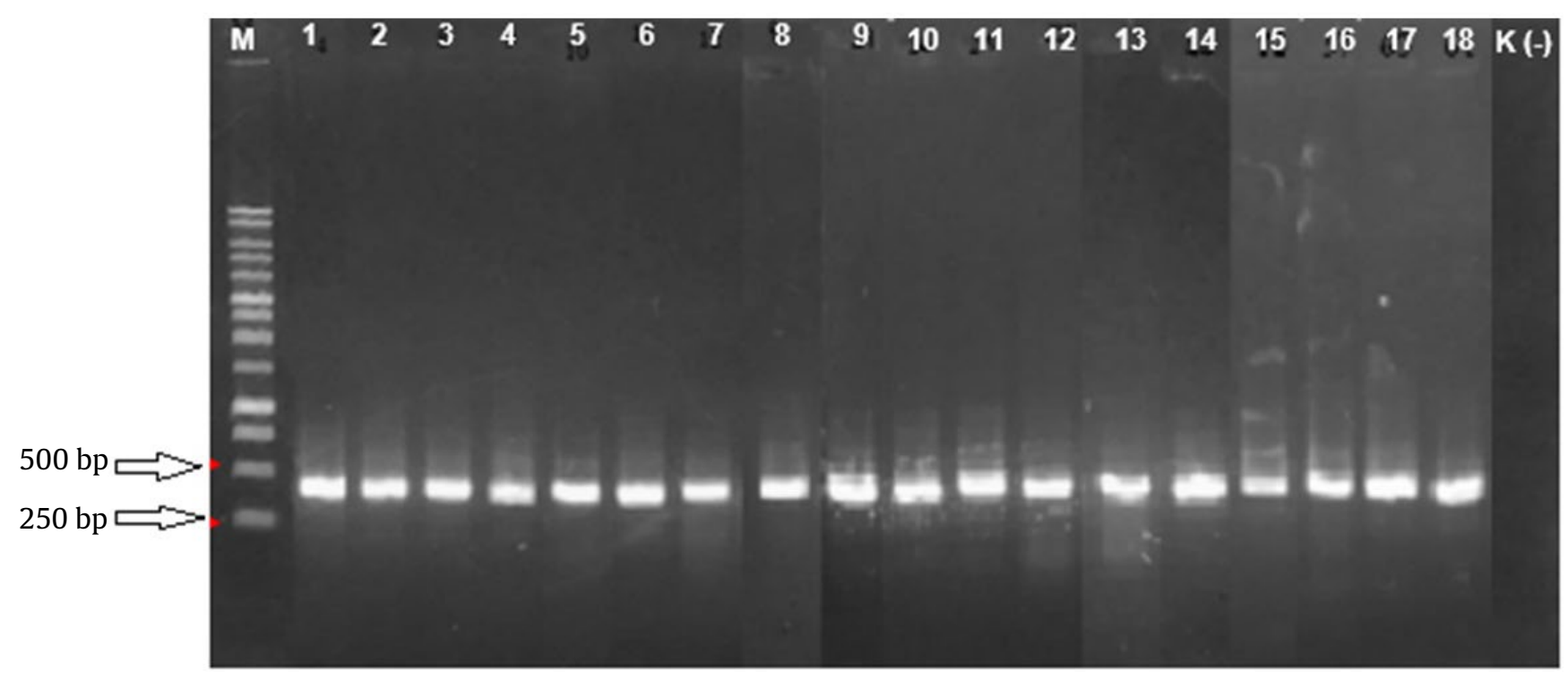

Figure 3. Electrophoresis results of the ITS2 amplicons: M. 1 kb DNA ladder, (1) Mas Bali, (2) Tulang/Ambon Hijau Bali, (3) Seribu, (4) Kepok Tanjung, (5) Rojo Molo, (6) Tembaga, (7) Klopok/Sobo, (8) Lumut, (9) Mas Marlin (10) Klutuk Bali, (11) Klutuk Wulung Galunggung, (12) Mas Subang, (13) Bile, (14) Ambon Hijau Papua, (15) Cavendish Sunpride, (16) Tongka Langit Galunggung, (17) Tongka Langit Maluku, (18) Kepok Jawa

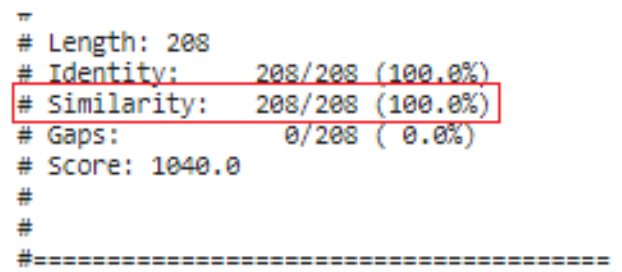

Tongka Langit Galunggung

Tongka Langit Maluku

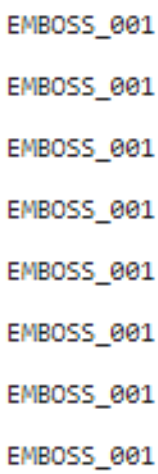

1 CGATTTCGACGCTTCGTCGGTACCCCCATTCGGCGAACGCGGAGGATGGCC

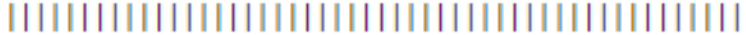

1 CGATTTCGACGCTTCGTCGGTACCCCATTCGGCGAACGCGGAGGATGGCC

51 CCCCGTGCCGGAAGGTGCGGTTGGCCGAAGAGCGGGCCGTCGTTGGTTAT |l||l|||||||||||||||||||||||||||||||||||||||||||| 51 CCCCGTGCCGGAAGGTGCGGTTGGCCGAAGAGCGGGCCGTCGTTGGTTAT

101 CGAACACGACGCGTGGTGGATGCCTTGCGCGAGCCGTACGTCGTGCCTTC |l|||||||||||||||||||||||||||||||||||||||||||||| 101 CGAACACGACGCGTGGTGGATGCCTTGCGCGAGCCGTACGTCGTGCCTTC

151 GGGACCCGGACGAGGCCTCGAGGACCCAAGCCGTGGCGCGAGTCGATGCC

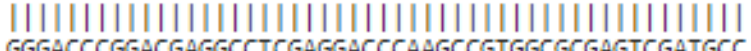
151 GGGACCCGGACGAGGCCTCGAGGACCCAAGCCGTGGCGCGAGTCGATGCC 280

50 50 108 108 158 150 280

Figure 4. Alignment of ITS2 sequence between Tongka Langit from Galunggung and Maluku. The numbers on either side of the sequence is the length in base pairs (bp). The red box shows the similarity between the nucleotide sequences from the two bananas

motif (TGGT sequences for DNA) in the 5' side. Helix II is characterized for containing a U-U mismatch motif (Schultz et al. 2005) and having a pyrimidinepyrimidine bulge (Coleman 2003). Meanwhile, Helix I and IV are less conserved than other helices, with Helix IV being the most rapidly evolving helix in plants and algae (Coleman 2003). Motifs found in the ITS2 secondary structure of Tongka Langit are the two U-U mismatches in Helix II and one UGGU motif in the 5' side in Helix III. These motifs are commonly found in plants (Bailey and Elkan 1994). Among the three motifs found in ITS2 of Tongka Langit, the U-U 


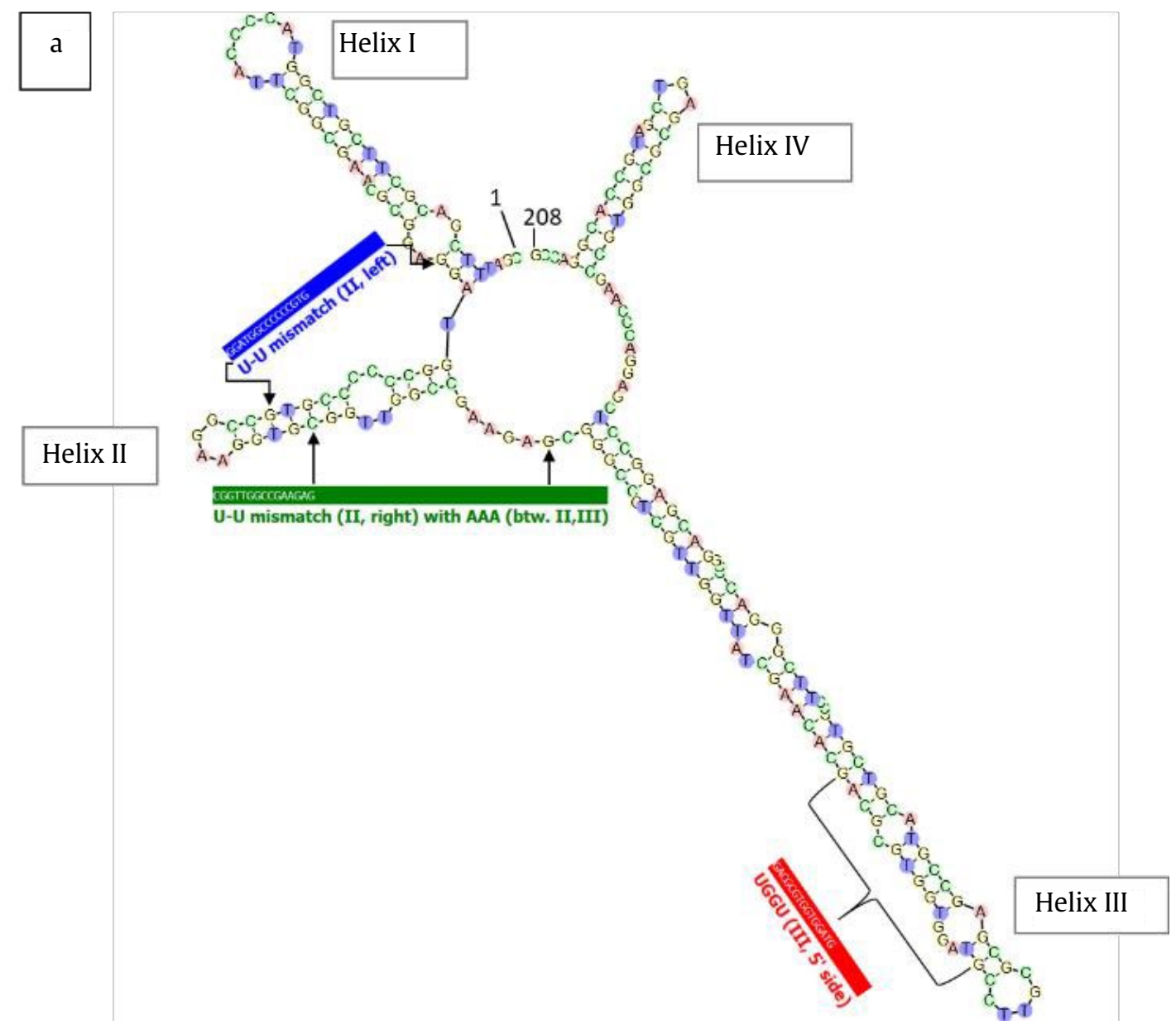

$\mathrm{b}$

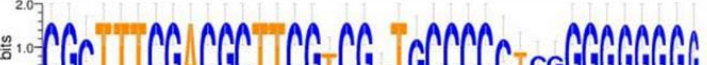

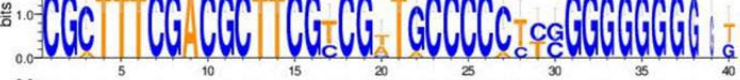

(II, left)

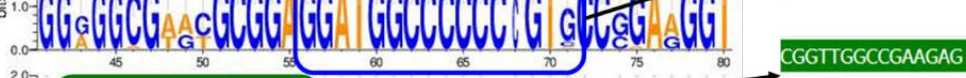

(b)

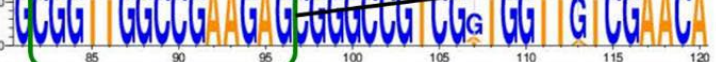

GACGGGGGGGATG

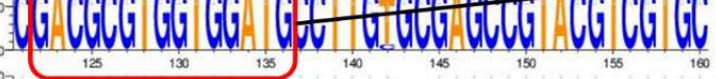

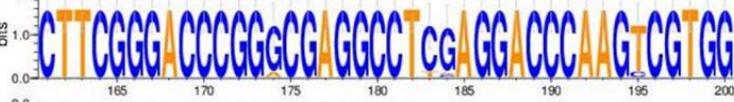

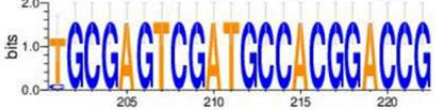

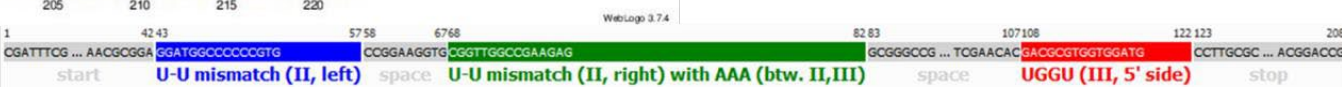

Figure 5. Secondary structure of ITS2 sequence of Tongka Langit and motif prediction of ITS2. (a) Secondary structure of ITS2 predicted from Tongka Langit, (b) consensus of ITS2 nucleotide sequences of 18 banana cultivars, represented in nucleotides logo. Probabilities of each nucleotides are represented in bits unit. The motifs of 208bp ITS2 sequence of Tongka Langit are predicted and then represented with boxes outlined with blue, green, and red color 

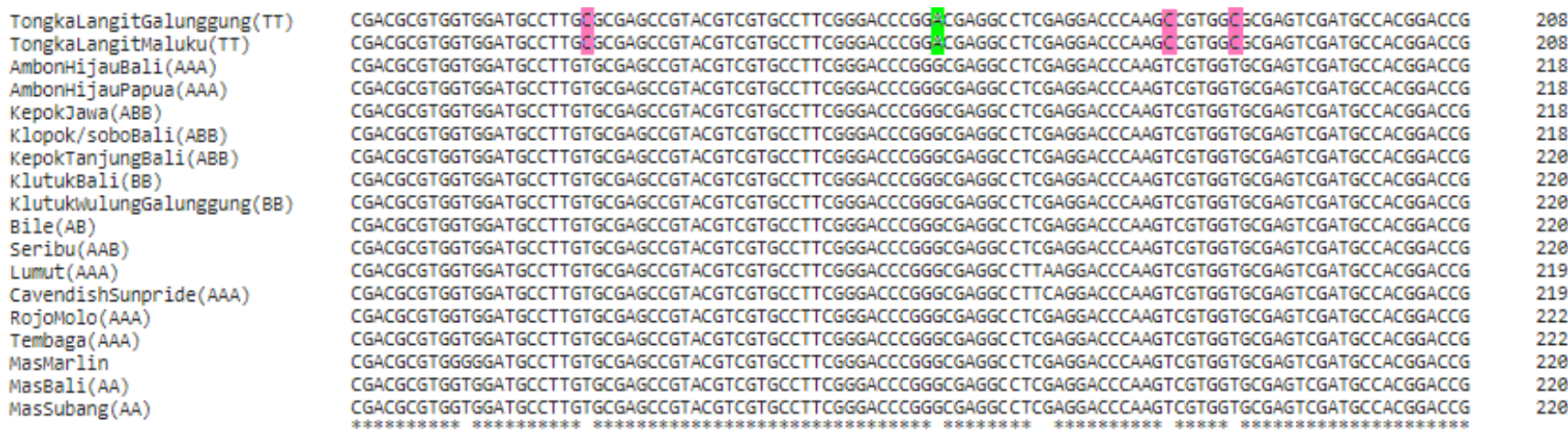

Figure 6. Multiple alignment between ITS2 sequence of Tongka Langit banana with banana cultivars with different genomes: Tongka Langit Galunggung, Tongka Langit Maluku, Ambon Hijau Bali, Ambon Hijau Papua, Kepok Jawa, Klopok/Sobo, Kepok Tanjung Bali, Klutuk Bali, Klutuk Wulung Galunggung, Bile, Seribu, Lumut, Cavendish Sunpride, Rojo Molo, Tembaga, Mas Marlin, Mas Bali, Mas Subang. Colored bases and red box show differences between Tongka Langit with banana cultivars from other genomes
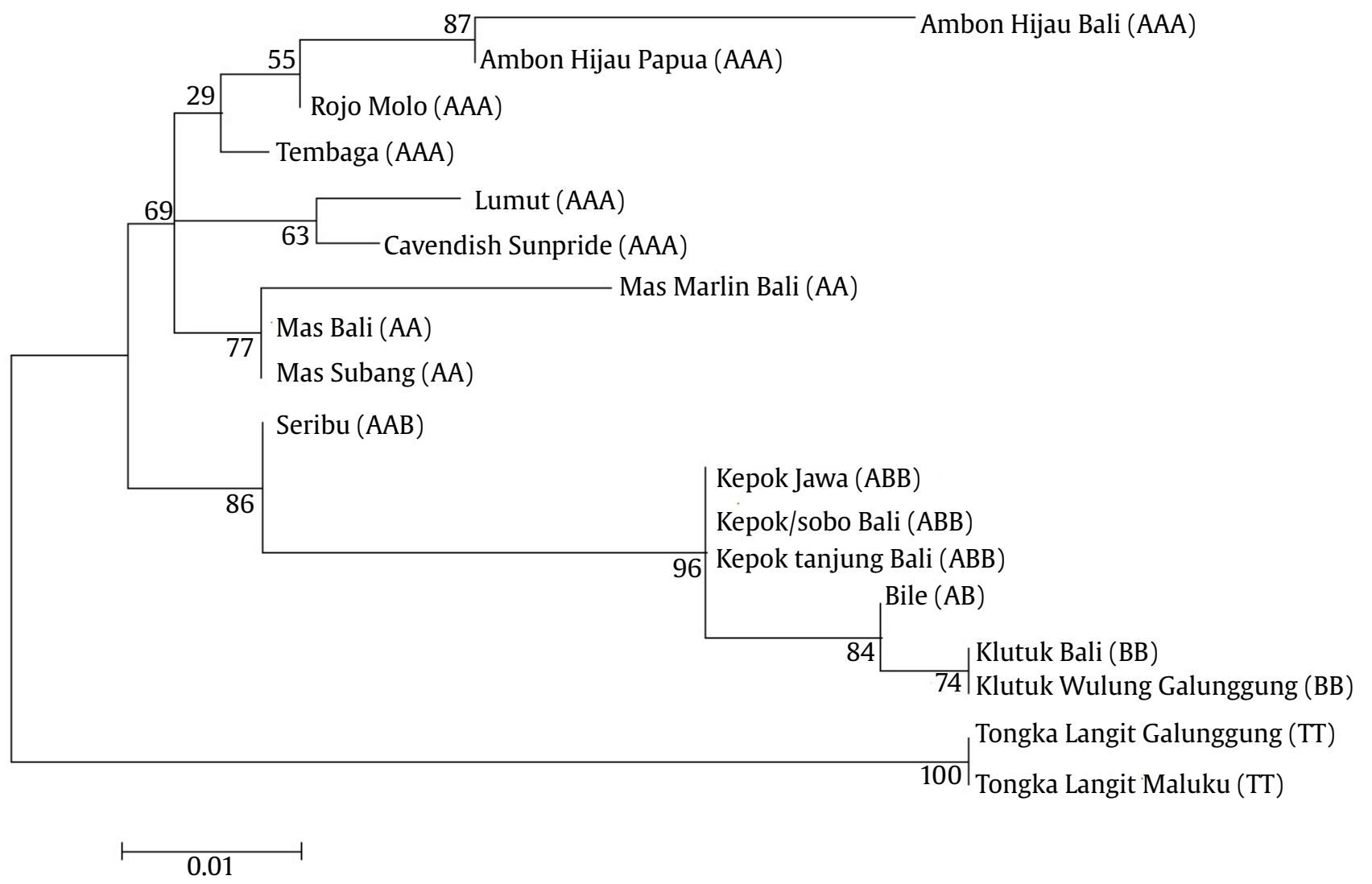

Figure 7. Dendrogram constructed with the maximum likelihood (ML) method, based on ITS2 marker of banana cultivars from different genomes. Tongka Langit bananas from Galunggung and Maluku formed an outgroup. Number under the branches are bootstrap probability (percent). Length of the branch represents the phylogenetic distance

mismatch in Helix II is less conserved; as this the case found in most plants (Bailey and Elkan 1994).

Furthermore, dendrogram analysis based on ITS2 marker showed that Tongka Langit banana with TT genome might have a different ancestor from other banana cultivars with other genomes (Hiariej and Karuwal 2015).

\section{Conclusion}

Based on the ITS2 sequence, Tongka Langit banana cultivar (TT genome) was distantly related and was thought to have a different ancestor from banana cultivars with different genomes ( $A A, A A A, A A B, A B$, $A B B$, and $B B)$. The ITS2 sequence of Tongka Langit 
Galunggung and Maluku were 100\% identical. This showed that Tongka Langit bananas from these two areas originated from a common ancestor.

\section{Acknowledgements}

We would like to thank Institut Teknologi Bandung, and Banana Group ITB that provided funds for the research as well as Bali International Research Center (BIRCB), Pattimura University, Indonesian Tropical Fruits Research Institute, Udayana University, and Universitas Pendidikan Indonesia that supported this study.

\section{References}

Altschul SF et al. 1997. Gapped BLAST and PSI-BLAST: a new generation of protein database search programs. Nucleic Acids Research 25:3389-3402.

Bailey TL, Elkan C. 1994. Fitting a mixture model by expectation maximization to discover motifs in biopolymers. In: Proceedings of the Second International Conference on Intelligent Systems for Molecular Biology. Menlo Park, California: AAAI Press. pp. 28-36.

Coleman AW. 2003. ITS2 is a double-edged tool for eukaryote evolutionary comparisons. TRENDS in Genetics 19:370375.

Crooks GE et al. 2004. WebLogo:a sequence logo generator. Genome Research 14:1188-1190.

Doyle P. 1990. DNA protocols for plants. In: Hewit G, Johnston A, Young J (Eds.). Molecular Techniques in Taxonomy. Berlin:Springer-Verlag. pp. 283-294.

Dwivany FM et al. 2020. Bali bananas (Musa spp. L.) genetic relationship based on internal transcribed spacer 2 (ITS2). Journal of Tropical Agricultural Science 43.

GLOBE. 2014. Soil Temperature Protocol. [ebook] Fort Collins, USA: GLOBE. Available at: https://www.globe.gov/ documents/352961/353769/Soil+Temperature+proto col/87a3491a-25af-4123-9e0c-08f341bfc004> [Date accessed: 22 September 2018]
Gu W et al. 2013. Application of the ITS2 region for barcoding medicinal plants of selaginellaceae in Pteridophyta. Plos One 8:1-8.

Hiariej A, Karuwal RL. 2015. Profil lingkungan tumbuh pisang Tongkat Langit (Musa troglodytarum L.) di Kabupaten Maluku Tengah. BioWallacea Jurnal Ilmiah Ilmu Biologi 1:59-63.

Keller A et al. 2009. 5.8S-28S rRNA interaction and HMMbased ITS2 annotation. Gene 430:50-57.

Koetschan C et al. 2010. The ITS2 Database III-283 sequences and structures for phylogeny. Nucleic Acids Research 38:275-279.

Lim TK. 2012. Edible Medicinal and Non-Medicinal Plants. Dordrecht:Springer.

Meitha K et al. 2020. Phylogenetic analysis of 23 accessions of Indonesian banana cultivars based on Internal Transcribed Spacer 2(ITS2) region. Indonesia Journal of Biotechnology 25:1-11. DOI:10.22146/ijbiotech.49506 www.jurnal.ugm.ac.id/ijbiotech

Ploetz RC et al. 2007. Banana and plantain--an overview with emphasis on Pacific Island cultivars. Available at: http://www.growables.org/information/TropicalFruit/ documents/BananaPlantainOverview.pdf [Date accessed: 11 February 2018]

Schultz J et al. 2005. A common core of secondary structure of the internal transcribed spacer 2 (ITS2) throughout the Eukaryota. RNA 11:361-364. DOI:10.1261/ rna.7204505

STEP Systems GmbH. 2005. Lux Meter Operating Instructions. Nürnberg:STEP Systems GmbH.

Tamura Ket al. 2013. MEGA6:molecular evolutionary genetics analysis version 6.0. Molecular Biology and Evolution 30:2725-2729.

Thompson JD et al. 1994. Clustal W: improving the sensitivity of progressive multiple sequence alignment through sequence weighting, position-specific gap penalties and weight matrix choice. Nucleic Acid Research 22:4673-4680.

Thomson G. 1986. The museum environment. Oxford: Butterworth Publishers.

Wonkee Donkee Tools. 2018. How to use a manual post-hole auger. Available at: https://www.wonkeedonkeetools. co.uk/manual-post-hole-augers/how-to-use-amanual-post-hole-auger/ [Date accessed:27 Juli 2018]

Yao $\mathrm{H}$ et al. 2010. Use of ITS2 Region as the universal DNA barcode for plants and animals. PLoS One 5:e13102. DOI: 10.1371/journal.pone.0013102 